\title{
Pengembangan bahan ajar digital pada materi sistem ekskresi manusia untuk siswa SMP kelas VIII
}

\author{
Arini Roichatul Jannah, Munzil*, Novida Pratiwi \\ Universitas Negeri Malang, Jl. Semarang No. 5 Malang, Jawa Timur, Indonesia \\ *Penulis korespondensi, Surel: munzil.fmipa@um.ac.id
}

Paper received: 01-03-2021; revised: 15-03-2021; accepted: 31-03-2021

\begin{abstract}
Abstrak
Tujuan dari penelitian ini adalah untuk menghasilkan bahan ajar digital pada materi sistem ekskresi manusia untuk siswa SMP kelas VIII yang valid dan layak. Model penelitian dan pengembangan yang dikembangkan diadopsi dari model pengembangan 4D (Four-D model) dari S. Thiagarajan, dkk (1974) tanpa menggunakan tahap disseminate. Kelayakan produk hasil pengembangan diperoleh dari uji validasi produk oleh ahli dan uji keterbacaan pada siswa. Data dalam penelitian ini adalah data kualitatif dan data kuantitatif. Data kualitatif didapatkan dari angket yang berisi tanggapan dan saran, sedangkan data kuantitatif didapatkan berdasarkan nilai rata-rata yang diperoleh dari skor angket validasi dengan menggunakan skala likert (skala bertingkat). Hasil uji validasi oleh ahli, menunjukkan bahwa produk sangat layak dengan persentase 97,3 persen untuk kelayakan materi dan 92 persen untuk kelayakan media. Berdasarkan uji keterbacaan pada siswa diperoleh persentase kelayakan bahan ajar digital sebesar 91,8 persen dan dapat dinyatakan bahwa bahan ajar digital yang dikembangkan sangat valid dan sangat layak. Dengan demikian bahan ajar digital pada materi sistem ekskresi manusia untuk siswa SMP Kelas VIII dinyatakan valid dan layak.
\end{abstract}

Kata kunci: bahan ajar; bahan ajar digital; multimedia; sistem ekskresi manusia

\section{Pendahuluan}

Ilmu pengetahuan Alam (IPA) merupakan salah satu cabang ilmu pengetahuan yang objek belajarnya adalah benda-benda alam. Belajar IPA berarti mempelajari segala sesuatu yang berkaitan dengan objek alam semesta, makhluk hidup dan tak hidup, dan materi dengan segala perubahan yang menyertainya (Salirawati, dkk, 2011). IPA berkaitan dengan cara mencari tahu tentang alam secara sistematis sehingga IPA bukan hanya penguasaan kumpulan pengetahuan yang berupa fakta-fakta, konsep-konsep, atau prinsip-prinsip saja, tetapi juga merupakan suatu proses penemuan (Trianto, 2012).

Bidang kajian IPA di SMP/MTs secara umum meliputi energi dan perubahannya, bumi antariksa, makhluk hidup dan proses kehidupan, materi dan sifatnya yang sebenarnya sangat berperan dalam membantu peserta didik untuk memahami fenomena alam (Trianto, 2012). IPA mempelajari fenomena alam yang dapat diamati indera maupun yang tidak dapat diamati dengan indera (Kardi dan Nur dalam Trianto, 2012). Materi tentang sistem ekskresi pada manusia merupakan contoh fenomena yang prosesnya tidak dapat diamati dengan indera, karena kajiannya yang mencakup proses fisiologi yang terjadi di dalam tubuh manusia. Sistem ekskresi merupakan salah satu konsep yang cukup sulit karena banyak hafalan, terlalu banyak istilah, dan beberapa faktor lainnya (Hanifah dalam Ibrahim, 2014).

Dalam pembelajarannya materi IPA yang tidak dapat diamati dengan indera hanya diajarkan dengan menggunakan metode ceramah siswa akan kesulitan memahami konsep tersebut. Bila guru hanya mentransfer materi yang terdapat dalam buku pelajaran kepada siswa, keaktifan belajar siswa rendah dan siswa juga akan merasa jenuh dan bosan. Pada 
akhirnya hasil belajar siswa kurang maksimal (Ariwibowo \& Parmin, 2015; Mulyadi, dkk., 2016; Wismadi, 2013).

Faktanya di lapangan menunjukkan bahwa, kegiatan pembelajaran di sekolah saat ini masih menggunakan buku teks dan lembar kerja siswa (LKS) sebagai sumber belajar. LKS hanya berisi rangkuman materi yang sangat dangkal dan tidak dilengkapi dengan gambar/ ilustrasi tentang materi yang dipelajari. Buku teks dan LKS yang digunakan tersebut dirasakan oleh siswa masih kurang memberikan pemahaman terhadap materi yang dipelajari, sehingga dibutuhkan media pembelajaran pendukung yang dapat membantu memperjelas materi (Merdekawati, dkk., 2014; Pramana \& Dewi, 2014, Widayat, dkk., 2014).

Bahan ajar yang dipakai siswa sangat berpengaruh dalam proses mentransfer konsep dan keterampilan dari guru ke siswa. Menurut Lestari (2013) bahan ajar adalah sumber belajar yang sampai saat ini memiliki peranan penting untuk menunjang proses pembelajaran. Bahan ajar menurut Majid (2013) adalah segala bentuk bahan, informasi, alat, dan teks yang digunakan untuk membantu guru dalam melaksanakan kegiatan belajar mengajar. Bahan tersebut dapat tertulis seperti buku maupun bahan tidak tertulis. Dengan adanya bahan ajar, guru dapat mengelola kegiatan pembelajaran secara efektif dan efisien, selain itu semua kompetensi yang telah ditentukan sebelumnya akan tercapai (Lestari, 2013).

Seiring dengan perkembangan zaman dan Ilmu Pengetahuan dan Teknologi (IPTEK) banyak siswa yang memilih membawa laptop daripada membawa buku teks pelajaran. Buku teks yang tebal dan berat merepotkan siswa untuk membawanya ke sekolah. Siswa menginginkan semuanya serba praktis, hanya dengan soft file yang dapat diakses dengan laptop sehingga tidak perlu membawa buku-buku yang ukurannya besar ke sekolah. Penggunaan teknologi berbasis komputer merupakan cara untuk menghasilkan atau menyampaikan materi dengan menggunakan sumber-sumber yang berbasis microprosessor, dimana informasi atau materi yang disampaikan disimpan dalam bentuk digital, bukan dalam bentuk cetakan. Selain itu, teknologi komputer merupakan solusi dalam penyediaan multimedia untuk mendukung pembelajaran yang lebih optimal (Nugroho, 2015; Ulfa, 2013; Sunardi, 2010).

Multimedia interaktif merupakan kombinasi dua atau lebih media (audio, teks, grafik, gambar, aimasi, dan video) yang oleh penggunanya dimanipulasi untuk mengendalikan perintah atau perilaku alami dari suatu presentasi (Majid, 2013). Penggunaan multimedia dalam proses pembelajaran dapat membuat konsep yang tidak dapat divisualisasikan menjadi lebih konkrit sehingga siswa mudah memahami konsep yang diajarkan (Fathiyati \& Utami, 2012; Munir, 2012). Selain itu, dengan adanya multimedia potensi indera siswa dapat diakomodasikan sehingga hasil belajar siswa akan meningkat (Deliyannis, 2012). Oleh karena itu, dibutuhkan inovasi baru berupa pengembangan bahan ajar yang dilengkapi dengan multimedia interaktif atau dapat disebut dengan bahan ajar digital.

Berdasarkan uraian tersebut, maka peneliti ingin mengembangkan bahan ajar digital sebagai upaya mewujudkan kualitas pembelajaran yang efektif dan mempermudah siswa dalam memahami materi sistem ekskresi manusia. Sehingga penelitian dan pengembangan ini diberi judul "Pengembangan Bahan Ajar Digital pada Materi Sistem Ekskresi Manusia untuk Siswa SMP Kelas VIII" 


\section{Metode}

Model penelitian dan pengembangan yang digunakan dalam penelitian ini diadopsi dari model pengembangan 4D (Four-D model) dari S. Thiagarajan, dkk (1974). Tahapantahapan dari model pengembangan ini ada empat tahap yaitu define, design, develop, dan disseminate atau diadaptasikan menjadi model $4 \mathrm{P}$ yaitu pendefinisian, perancangan, pengembangan dan penyebaran. Namun dalam pengembangan bahan ajar digital ini hanya dilakukan sampai pada tahap yang ketiga, yakni tahap pengembangan (develop).

Tahap-tahap dalam pengembangan bahan ajar digital, antara lain (1) Tahap pendefinisian (define) meliputi analisis awal-akhir, analisis siswa, analisis materi pembelajaran, dan perumusan tujuan pembelajaran; (2) Tahap perancangan (design) meliputi penentuan desain produk bahan ajar, penyusunan draft awal bahan ajar, dan pemrogaman; (3) Tahap pengembangan (develop) meliputi penilaian validasi oleh ahli (validasi media dan materi), perbaikan atau revisi, dan uji coba kelayakan produk.

Uji validitas dilakukan dua kali, yaitu uji kelayakan bahan ajar dan uji coba lapangan terbatas. Uji kelayakan bahan ajar dilakukan oleh ahli media, ahli materi dan juga ahli praktisi lapangan, sedangkan uji lapangan terbatas dilakukan kepada 10 siswa SMP kelas VIII. Instrumen yang digunakan untuk memperoleh data berupa angket penilaian dalam bentuk checklist yang menilai tampilan bahan ajar, kebenaran konsep, kesesuaian materi maupun komponen-komponen penyajian materi hasil pengembangan. Jawaban dari angket penilaian tampilan bahan ajar dan kesesuaian materi menggunakan skala likert 4 tingkat. Lembar validasi materi (kebenaran konsep) menggunakan skala Guttman yaitu keterangan "ya" dan "tidak" atau "benar" dan "salah". Teknik analisis data yang digunakan adalah teknik analisis persentase. Menentukan nilai (\%) kriteria kelayakan menggunakan rumus sebagai berikut.

$$
P=\frac{\sum x}{n} \times 100 \%
$$

Keterangan:

P : Persentase

$\sum \mathrm{x} \quad$ : Jumlah keseluruhan jawaban responden

n : Jumlah skor tertinggi (Widoyoko, 2015).

Setelah ditemukan persentase hasil subjek uji coba, selanjutnya dilakukan pemaknaan terhadap hasil tersebut, terdapat pada Tabel 1 berikut.

Tabel 1 Persentase Hasil Penilaian

\begin{tabular}{lll}
\hline Persentase & Layak & Valid \\
\hline $81 \%-100 \%$ & Sangat layak & Sangat valid \\
$61 \%-80 \%$ & Layak & Valid \\
$41 \%-60 \%$ & Cukup layak & Cukup valid \\
$21 \%-40 \%$ & Tidak layak & Tidak valid \\
$0 \%-20 \%$ & Sangat tidak layak & Sangat tidak valid \\
\hline
\end{tabular}

(Sumber : Riduwan, 2006) 


\section{Hasil dan Pembahasan}

\subsection{Deskripsi Produk Hasil Pengembangan}

Pengembangan yang dilakukan dalam penelitian ini menghasilkan suatu produk bahan ajar digital pada materi sistem ekskresi manusia. Materi yang terdapat pada bahan ajar digital dikembangkan berdasarkan KD yang diperoleh dari Silabus Kurikulum 2013. Produk ini dapat digunakan sebagai suplemen pembelajaran siswa SMP/ MTs Kelas VIII. Bahan ajar digital dikemas dalam bentuk aplikasi (.exe) untuk laptop atau komputer.

Proses belajar siswa pada bahan ajar digital dimulai dengan adanya apersepsi berupa permasalahan maupun gambar yang berkaitan dengan materi. Setelah itu, pada bahan ajar digital disajikan kegiatan saintifik dimulai dari kegiatan mengamati dengan menampilkan video, kegiatan menanya dengan menjawab pertanyaan, kegiatan mengumpulkan informasi dengan melakukan percobaan sederhana maupun dengan game flash mencocokkan struktur organ ekskresi, kegiatan mengasosiasi dengan berdiskusi menjawab pertanyaan, dan kegiatan mengkomunikasikan dengan mempresentasikan hasil diskusi. Sebelum penyajian materi, disediakan soal uji pemahaman konsep dalam bentuk pilihan ganda yang dikemas dalam flash. Pada akhir materi disajikan soal evaluasi terkait dengan empat subbab yang telah dibahas. Beberapa tampilan bahan ajar digital hasil pengembangan disajikan pada Gambar 1 berikut.

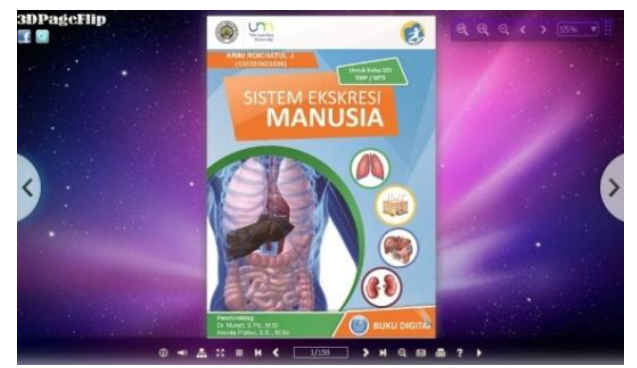

Tampilan Halaman Awal Bahan Ajar Digital (Cover)

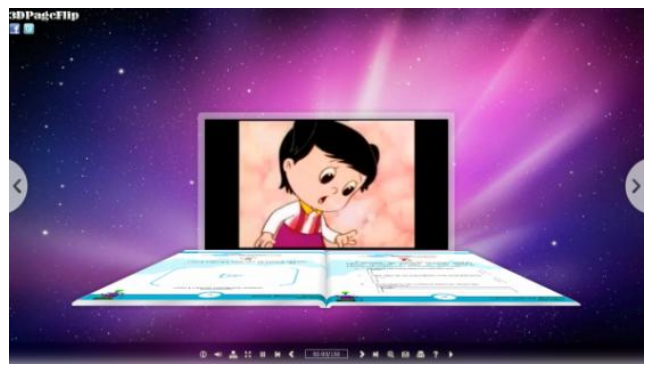

Tampilan Video saat diputar 


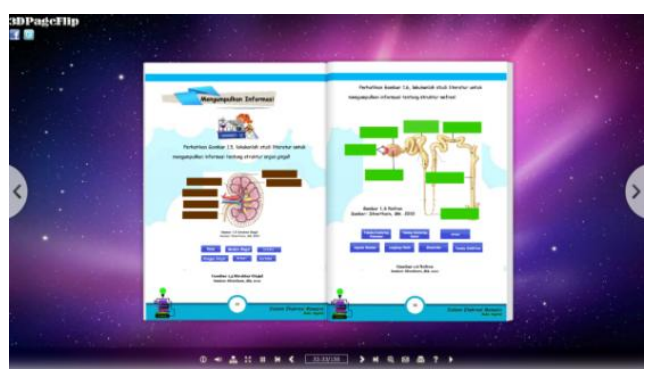

Tampilan Game Flash Mencocokkan Nama Organ

Gambar 1. Tampilan Produk Bahan Ajar Digital

\subsection{Hasil Validasi Produk}

Uji validasi dilaksanakan oleh tiga ahli yaitu ahli materi, ahli media, dan ahli praktisi lapangan. Uji validasi ahli materi dan media dilakukan oleh dosen Biologi Universitas Negeri Malang. Data kuantitatif hasil uji validasi materi dibedakan menjadi dua, yaitu data uji validasi kebenaran konsep dan data uji validasi kesesuaian materi. Data kuantitatif hasil uji validasi kebenaran konsep dapat dilihat pada Tabel 2 berikut.

\section{Tabel 2 Data Kuantitatif Hasil Uji Validasi Kebenaran Konsep}

\begin{tabular}{cll}
\hline No & Konsep & Persentase \\
\hline 1. & Pendahuluan (Sistem Ekskresi & $100 \%$ \\
& Manusia) & \\
2. & Subbab Ginjal & $100 \%$ \\
3. & Subbab Kulit & $100 \%$ \\
4. & Subbab Paru-paru & $100 \%$ \\
5. & Subbab Hati & $100 \%$ \\
\hline Nilai Rata-rata & $\mathbf{1 0 0 \%}$ \\
\hline
\end{tabular}

Berdasarkan data hasil kebenaran konsep pada bahan ajar digital ini memperoleh persentase sebesar $100 \%$. Bahan ajar dapat dikatakan layak jika tidak terdapat kesalahan konsep, sehingga dari hasil persentase tersebut, bahan ajar digital yang dikembangkan sudah layak untuk digunakan. Uji validasi materi selanjutnya adalah tentang kesesuaian materi. Data kuantitatif hasil uji validasi kesesuaian materi dapat dilihat pada Tabel 3 berikut. 
Tabel 3 Data Kuantitatif Hasil Uji Validasi Kesesuaian Materi

\begin{tabular}{lllll}
\hline No & Aspek yang dinilai & Rerata & Persentase & Keterangan \\
\hline 1. & Desain Pembelajaran & 4,00 & $100 \%$ & Sangat Layak \\
2. & Kejelasan Materi & 3,75 & $94 \%$ & Sangat Layak \\
3. & Kesesuaian Gambar dengan & 3,75 & $94 \%$ & Sangat Layak \\
& Materi & 3,75 & $94 \%$ & Sangat Layak \\
4. & Kesesuaian Video dengan Materi & 4,00 & $100 \%$ & Sangat Layak \\
5. & Keluasan Materi & 4,00 & $100 \%$ & Sangat Layak \\
6. & Kemudahan dalam Memahami & & & \\
Materi & Kesesuaian Soal Pemahaman & 4,00 & $100 \%$ & Sangat Layak \\
& $\quad$ Konsep dengan Materi yang & & & \\
& disajikan & 4,00 & $100 \%$ & Sangat Layak \\
8. Soal Evaluasi & 3,91 & $98 \%$ & Sangat Layak \\
\hline
\end{tabular}

Berdasarkan Tabel 3, persentase kesesuaian materi yang terdapat pada bahan ajar digital memperoleh hasil sebesar 98\% dan dinyatakan bahwa kesesuaian materi sangat layak. Namun, terdapat saran dari validator materi untuk perbaikan kebenaran konsep maupun kesesuaian materi yang ada pada bahan ajar digital. Saran pembenaran kebenaran konsep dapat dilihat pada Tabel 4 berikut.

Tabel 4 Data Kualitatif Hasil Uji Validasi Materi (Kebenaran Konsep)

\begin{tabular}{ll}
\hline No & Saran Validator \\
\hline 1. & $\begin{array}{l}\text { Pada Subbab Ginjal perlu perbaikan untuk praktikum uji urin protein karena } \\
\text { alat di SMP harus lengkap (ada sentrifuge) agar tidak bias. Jika tidak bisa maka } \\
\text { praktikum uji urin protein lebih baik dihilangkan. }\end{array}$ \\
2. & $\begin{array}{l}\text { Pada subbab ginjal terdapat kesalahan konsep pada deskripsi sumsum ginjal } \\
\text { (medula), seharusnya hanya ditulis medula. }\end{array}$ \\
\hline
\end{tabular}

Sedangkan data kualitatif berupa saran dari validator materi untuk kesesuaian materi dapat dilihat pada Tabel 5 berikut.

Tabel 5 Data Kualitatif Hasil Uji Validasi Materi (Kesesuaian Materi)

\begin{tabular}{ll}
\hline No & Saran Validator \\
\hline 1. & Pada Pendahuluan perlu diperbaiki untuk kesalahan ketik/ ejaan \\
2. & Pada Subbab Kulit perlu diperbaiki untuk kesalahan ketik/ ejaan \\
3. & Pada Subbab Paru-paru untuk gambar hidung, faring dan laring disatukan \\
\hline
\end{tabular}

Kegiatan validasi media pembelajaran menghasilkan data kuantitatif dan data kualitatif. Data kuantitatif hasil uji validasi media dapat dilihat pada Tabel 6 berikut. 
Tabel 6 Data Kuantitatif Hasil Uji Validasi Media

\begin{tabular}{lllll}
\hline No & Aspek yang dinilai & Rerata & Persentase & Keterangan \\
\hline 1. & Tampilan Bahan Ajar Digital & 4,00 & $100 \%$ & Sangat Layak \\
2. & Penyajian Gambar & 3,67 & $92 \%$ & Sangat Layak \\
3. & Penyajian Video & 4,00 & $100 \%$ & Sangat Layak \\
4. & Penyajian Soal Pemahaman Konsep & 4,00 & $100 \%$ & Sangat Layak \\
5. & Penyajian Soal Evaluasi & 4,00 & $100 \%$ & Sangat Layak \\
6. & Rekayasa Perangkat Lunak & 4,00 & $100 \%$ & Sangat Layak \\
7. & Komunikasi Visual & 3,75 & $94 \%$ & Sangat Layak \\
\hline Nilai Rata-rata & 3,92 & $98 \%$ & Sangat Layak \\
\hline
\end{tabular}

Berdasarkan data hasil uji validasi media, bahan ajar digital yang telah dikembangkan memperoleh hasil rerata sebesar 98\% dan dinyatakan bahwa media sangat layak. Selain data kuantitatif, validator juga memberikan data kualitatif berupa saran dan komentar yang digunakan untuk perbaikan media pada bahan ajar digital. Saran tersebut dapat dilihat pada Tabel 7 berikut.

Tabel 7 Data Kualitatif Hasil Uji Validasi Media

\begin{tabular}{ll}
\hline No & Saran Validator \\
\hline 1. & Pada halaman sampul (cover) ditambahkan NIM pengembang bahan ajar digital \\
2. & $\begin{array}{l}\text { Pada Subbab Ginjal video yang terdapat pada kegiatan mengamati perlu } \\
\text { dipotong dan diperjelas suaranya. }\end{array}$ \\
3. & $\begin{array}{l}\text { Pada Subbab Kulit video yang terdapat pada kegiatan mengamati perlu } \\
\text { diperjelas suaranya. }\end{array}$ \\
4. & $\begin{array}{l}\text { Pada Subbab Paru-paru video yang terdapat pada kegiatan mengamati perlu } \\
\text { diperjelas suaranya. }\end{array}$ \\
\hline
\end{tabular}

Ahli praktisi lapangan untuk validasi bahan ajar digital yang telah dikembangkan adalah dua orang guru IPA SMP. Data kuantitatif yang didapatkan dari hasil validasi ahli praktisi lapangan dibedakan menjadi dua, yaitu data kuantitatif kesesuaian materi dan data kuantitatif media. Data kuantitatif hasil uji validasi kesesuaian materi dapat dilihat pada Tabel 8 berikut.

\section{Tabel 8 Data Kuantitatif Hasil Uji Validasi Kesesuaian Materi}

\section{oleh Ahli Praktisi Lapangan}

\begin{tabular}{lllll}
\hline No & Aspek yang dinilai & Rerata & Persentase & Keterangan \\
\hline 1. & Desain Pembelajaran & 4,00 & $100 \%$ & Sangat Layak \\
2. & Kejelasan Materi & 3,89 & $97,3 \%$ & Sangat Layak \\
3. & Kesesuaian Gambar dengan & 3,38 & $84,5 \%$ & Sangat Layak \\
& Materi & 3,13 & $78,3 \%$ & Layak \\
4. & Kesesuaian Video dengan Materi & 3,75 & $93,8 \%$ & Sangat Layak \\
5. Keluasan Materi & Kemudahan dalam Memahami & 3,63 & $90,6 \%$ & Sangat Layak \\
6. & & & \\
Materi & Kesesuaian Soal Pemahaman & 3,75 & $93,8 \%$ & Sangat Layak \\
& Konsep dengan Materi yang & & & \\
& disajikan & 3,50 & $87,5 \%$ & Sangat Layak \\
8. Soal Evaluasi & 3,63 & $90,8 \%$ & Sangat Layak \\
\hline Nilai Rata-rata & & & \\
\end{tabular}


Sedangkan data kuantitatif hasil uji validasi media oleh ahli praktisi lapangan dilihat pada Tabel 9 berikut.

Tabel 9 Data Kuantitatif Hasil Uji Validasi Media oleh Ahli Praktisi Lapangan

\begin{tabular}{lllll}
\hline No & Aspek yang dinilai & Rerata & Persentase & Keterangan \\
\hline 1. & Tampilan Bahan Ajar Digital & 3,41 & $85,4 \%$ & Sangat Layak \\
2. & Penyajian Gambar & 3,31 & $83,3 \%$ & Sangat Layak \\
3. & Penyajian Video & 3,50 & $87,5 \%$ & Sangat Layak \\
4. & Penyajian Soal Pemahaman Konsep & 4,00 & $100 \%$ & Sangat Layak \\
5. & Penyajian Soal Evaluasi & 4,00 & $100 \%$ & Sangat Layak \\
6. & Rekayasa Perangkat Lunak & 3,65 & $91,8 \%$ & Sangat Layak \\
7. & Komunikasi Visual & 3,13 & $78,3 \%$ & Layak \\
\hline Nilai & Rata-rata & 3,46 & $86,5 \%$ & Sangat Layak \\
\hline
\end{tabular}

Berdasarkan data hasil uji validasi kelayakan bahan ajar dari ahli praktisi lapangan, kesesuian materi pada bahan ajar digital ini memperoleh hasil rerata sebesar 90,8\% dan dinyatakan bahwa kesesuaian materi pada bahan ajar digital sangat layak. Sedangkan data hasil uji validasi media pada bahan ajar digital oleh ahli praktisi lapangan memperoleh rerata sebesar $86,5 \%$ dan dinyatakan bahwa media pada bahan ajar digital sangat layak. Selain data kuantitatif, ahli praktisi lapangan juga memberikan data kualitatif berupa saran dan komentar yang digunakan untuk perbaikan materi maupun media pada bahan ajar digital. Saran tersebut dapat dilihat pada Tabel 10 berikut.

\section{Tabel 10 Saran Hasil Uji Validasi Materi dan Media oleh Ahli Praktisi Lapangan}

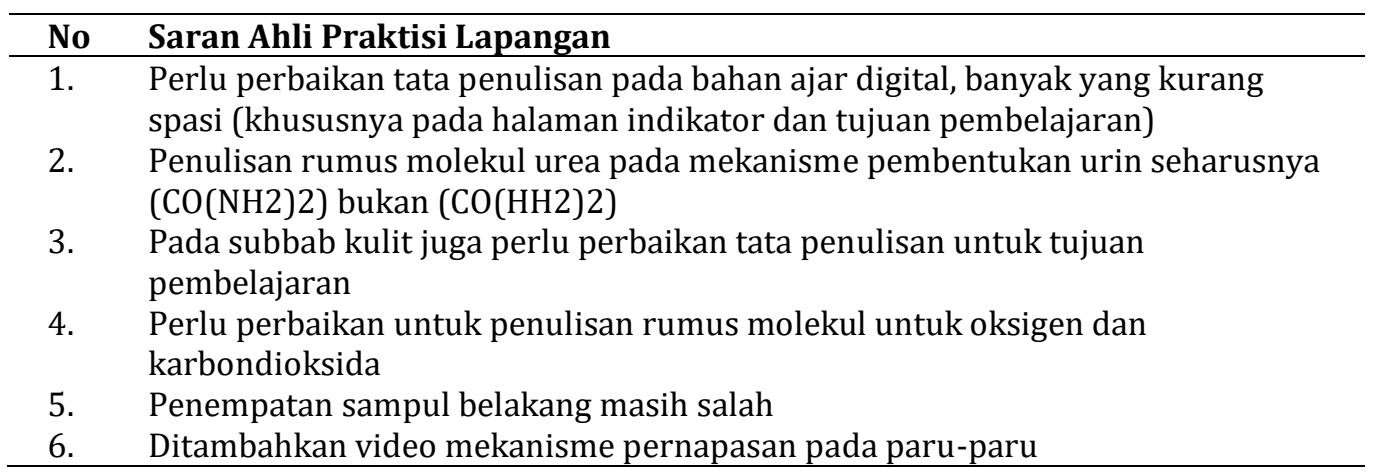

\subsection{Hasil Uji Keterbacaan}

Uji keterbacaan bahan ajar digital dilakukan pada 10 siswa SMP kelas VIII. Hasil uji keterbacaan dapat dilihat pada Tabel 11 berikut.

Tabel 11 Data Kuantitatif Hasil Uji Keterbacaan pada Siswa

\begin{tabular}{|c|c|c|c|c|}
\hline No & Aspek yang dinilai & Rerata & Persentase & Keterangan \\
\hline 1. & $\begin{array}{l}\text { Tampilan Bahan } \\
\text { Ajar Digital }\end{array}$ & 3,70 & $92,5 \%$ & Sangat Layak \\
\hline 2. & Penyajian Materi & 3,55 & $88,8 \%$ & Sangat Layak \\
\hline
\end{tabular}




\begin{tabular}{|c|c|c|c|c|}
\hline 3. & $\begin{array}{l}\text { Penyajian Soal } \\
\text { Evaluasi }\end{array}$ & 3,65 & $91,3 \%$ & Sangat Layak \\
\hline 4. & Komunikasi Visual & 3,76 & $94 \%$ & Sangat Layak \\
\hline \multicolumn{2}{|c|}{ Nilai Rata-rata } & 3,67 & $91,8 \%$ & Sangat Layak \\
\hline
\end{tabular}

Berdasarkan data hasil uji keterbacaan pada siswa memperoleh hasil rerata sebesar 91,8\% dan dinyatakan bahwa bahan ajar digital sangat layak untuk digunakan. Saran yang diberikan oleh siswa dapat dilihat pada Tabel 12 berikut.

\section{Tabel 12 Saran dan Komentar Hasil Uji Keterbacaan bahan Ajar Digital oleh Siswa}

\begin{tabular}{cl}
\hline No & Saran dan Komentar Siswa \\
\hline 1. & $\begin{array}{l}\text { Bahan ajar digital yang dikembangkan secara keseluruhan sudah bagus, bisa } \\
\text { dipahami dan dapat membuat siswa termotivasi untuk belajar }\end{array}$ \\
2. & $\begin{array}{l}\text { Bahan ajar digital yang dikembangkan sangat menarik } \\
\text { Adanya gambar dan video dalam bahan ajar digital dapat mempermudah }\end{array}$ \\
s. & $\begin{array}{l}\text { Adanya game dalam bahan ajar digital dapat membuat siswa tidak jenuh } \\
\text { dalam belajar }\end{array}$ \\
5. & Saat mengisi jawaban pada kolom menanya masih terjadi eror \\
\hline
\end{tabular}

\section{Simpulan}

\subsection{Kesimpulan}

Produk yang dihasilkan dalam penelitian dan pengembangan ini adalah Bahan Ajar Digital pada Materi Sistem Ekskresi Manusia untuk Siswa SMP Kelas VIII. Bahan Ajar Digital pada Materi Sistem Ekskresi Manusia terdiri dari empat subbab, yaitu subbab ginjal, kulit, paru-paru, dan hati. Pada setiap subbab materi diawali dengan apersepsi atau pemberian masalah melalui gambar maupun pertanyaan yang sesuai dengan subbab yang akan dibahas. Selain itu pada bahan ajar digital juga terdapat kegiatan saintifik dimulai dari kegiatan mengamati, menanya, mengumpulkan informasi, mengasosiasi hingga mengkomunikasikan. Setelah kegiatan saintifik, akan disajikan uji pemahaman konsep untuk mengecek pemahaman siswa terhadap kegiatan yang telah dilakukan. Kemudian diberikan pembahasan materi pada kegiatan "Ayo Kita Membaca". Produk akhir dari bahan ajar digital akan dikemas dalam bentuk CD (Compact Disk).

Berdasarkan hasil Uji Validasi produk diperoleh persentase sebesar 100\% untuk kebenaran konsep dan 98\% untuk kesesuaian materi, sehingga dapat dinyatakan bahwa materi yang ada pada bahan ajar digital sangat valid dan sangat layak. Hasil validasi media oleh ahli media, diperoleh persentase kelayakan sebesar 98\%, sehingga dapat dinyatakan bahwa media yang ada pada bahan ajar digital sangat layak dan sangat valid. Hasil validasi oleh ahli praktisi lapangan yang dilakukan oleh dua guru IPA diperoleh persentase kelayakan sebesar 90,8\% untuk kesesuaian materi dan $86,5 \%$ untuk media sehingga dapat dinyatakan bahwa bahan ajar digital sangat layak dan sangat valid. Berdasarkan hasil uji keterbacaan pada 10 siswa SMP Kelas VIII diperoleh persentase kelayakan bahan ajar digital sebesar 91,8\% sehingga dapat dinyatakan bahwa bahan ajar digital yang dikembangkan 
sangat layak untuk digunakan. Sehingga dapat disimpulkan bahwa penelitian dan pengembangan ini menghasilkan produk berupa bahan ajar digital pada materi sistem ekskresi manusia untuk siswa SMP Kelas VIII yang valid dan layak.

\subsection{Saran}

Saran pengembangan lebih lanjut adalah peneliti lain dapat memadukan bahan ajar digital ini, sehingga tidak hanya materi biologi, tetapi juga dikaitkan dengan fisika maupun kimia. Pengembangan lebih lanjut dapat dilakukan uji coba secara empirik dengan sampel yang lebih luas. Uji empirik dilakukan untuk mengetahui keefektifan bahan ajar digital ini dalam pembelajaran IPA.

\section{Daftar Rujukan}

Ariwibowo, P., \& Parmin, P. (2015). PENGEMBANGAN AUDIO VISUAL SISTEM SIRKULASI DARAH YANG BERPENDEKATAN SAINTIFIK. Unnes Science Education Journal, 4(2).

Deliyannis, I. (Ed.). (2012). Interactive multimedia. BoD-Books on Demand.

Fathiyati, R., \& Utami, R. P. (2012). Pengembangan media pembelajaran Biologi berbasis macromedia flash sebagai sumber belajar bagi siswa SMA/MA kelas XI semester 2 Materi pokok sistem reproduksi manusia. In Prosiding Seminar Biologi (Vol. 9, No. 1).

Ibrahim, A. (2013). Penerapan Learning Log Class untuk Mendiagnostik Kesulitan Belajar Siswa SMA Pada Materi Sistem Ekskresi (Doctoral dissertation, Universitas Pendidikan Indonesia).

Lestari, I. (2013). Pengembangan bahan ajar berbasis kompetensi. Padang: Akademia Permata, 1.

Majid, A. (2013). Strategi pembelajaran. Bandung: PT. Remaja Rosdakarya.

Merdekawati, A. D. C., Saputro, S., \& Sugiharto, S. (2014). Pengembangan one stop learning multimedia menggunakan software adobe flash pada materi bentuk molekul dan gaya antar molekul kelas XI SMA. Jurnal Pendidikan Kimia, 3(1), 95-103.

Mulyadi, D. U., \& Wahyuni, S. (2016). Pengembangan media flash flipbook untuk meningkatkan keterampilan berfikir kreatif siswa dalam pembelajaran IPA di SMP. Jurnal Pembelajaran Fisika, 4(4), 296-301.

Munir, P. D. (2012). Multimedia konsep \& aplikasi dalam pendidikan.

Hari. N, Didiek. (2018). Panduan Praktis Membuat Dan Mempublikasi Video Bahan Ajar, Yogyakarta: Budi Utama

Pramana, W. D., \& Dewi, N. R. (2014). Pengembangan e-book IPA terpadu tema suhu dan pengukuran untuk menumbuhkan kemandirian belajar siswa. Unnes Science Education Journal, 3(3).

Riduwan, M. B. A. (2006). Belajar mudah penelitian untuk guru-karyawan dan peneliti pemula. Bandung: Alfabeta.

Salirawati, D., Subiantoro, A. W., \& Pujianto, P. (2011). Pelatihan Pengembangan Praktikum IPA Berbasis Lingkungan. INOTEKS, 15(1).

Sunardi, S. S. (2010). Multimedia pembelajaran tatasurya dengan pendekatan inkuiri bagi kelas X SMK. J. Teknologilnformasi, 6, 37-42.

Thiagarajan, S. (1974). Instructional development for training teachers of exceptional children: A sourcebook.

Ulfa, S. A. dkk. 2013. Pengembangan Modul IPA Elektronik Terpadu Berbasis Komputer untuk Siswa SMP dengan Tema Cahaya dalam Kehidupan Manusia sebagai Bahan Ajar Mandiri di SMP Negeri 1 Tulung Klaten dan SMP Negeri 2 Tempel Sleman. E-Journal Science Education UNY.

Widayat, W., Kasmui, K., \& Sukaesih, S. (2014). Pengembangan multimedia interaktif sebagai media pembelajaran ipa terpadu pada tema sistem gerak pada manusia. Unnes Science Education Journal, 3(2).

Widoyoko, E. P. (2012). Teknik penyusunan instrumen penelitian. Yogyakarta: Pustaka Pelajar, 15, 22.

Wismadi, R. H. (2013). PENGGUNAAN MULTIMEDIA INTERAKTIF DALAM PEMBELAJARAN IPA DI SMP. Jurnal Ilmiah Guru Caraka Olah Pikir Edukatif, (1). 